\title{
Greater promotion of DNRA rates and nrfA gene transcriptional activity by straw incorporation in alkaline than in acidic paddy soils
}

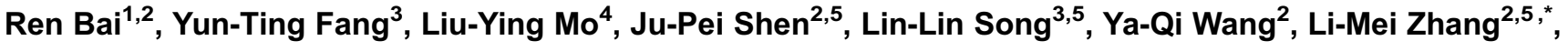 \\ Ji-Zheng $\mathrm{He}^{2,5}$ \\ 1 State Key Laboratory of Vegetation and Environmental Change, Institute of Botany, Chinese Academy of Sciences, Beijing 100093, China \\ 2 State Key Laboratory of Urban and Regional Ecology, Research Centre for Eco-Environmental Sciences, Chinese Academy of Sciences, \\ Beijing 100085, China \\ 3 CAS Key Laboratory of Forest Ecology and Management, Institute of Applied Ecology, Chinese Academy of Sciences, Shenyang 110016, \\ China \\ 4 Beihai Forestry Research Institute, Beihai 536000, China \\ 5 University of Chinese Academy of Sciences, Beijing 100049, China
}

\section{ARTICLE INFO}

\section{Article history:}

Received March 11, 2020

Revised May 12, 2020

Accepted June 17, 2020

\section{Keywords:}

DNRA

nrfA gene

Paddy soil

Straw

Nitrate reduction

\begin{abstract}
A B S T R A C T
Dissimilarity nitrate reduction to ammonium (DNRA) is of significance in agriculture ecosystems as the process is beneficial to $\mathrm{N}$ retention in soils. However, how fertilization regimes influence DNRA rates and functional microbes in agriculture was rarely estimated. In the present study, a 2-year pot experiment was conducted in two contrasting paddy soils to evaluate the effects of straw and nitrogen addition on DNRA process and the related functional microbes, using stable isotope tracer and molecular ecology techniques. The results showed that the abundance and transcription activity of nitrite reductase encoding gene ( $n r f A)$ involved in DNRA process and DNRA rates were significantly higher in alkaline soils than in acidic soils. Straw incorporation significantly enhanced $n r f A$ gene abundance and transcription activity, with a greater effect in alkaline soil than in acidic soil. The rates of DNRA, abundance and transcription activity of $n r f A$ gene positively correlated to soil $\mathrm{C} / \mathrm{N}$ and $\mathrm{C} / \mathrm{NO}_{3}{ }_{3}^{-}$ induced by straw application. Sequencing analysis based on nrfA gene transcript showed that Deltaproteobacteria was the most dominant group in both soil types $(30.9 \%-67.4 \%)$, while Gammaproteobacteria, Chloroflexi, Actinobacteria were selectively enriched by straw incorporation. These results demonstrated that DNRA activity can be improved by straw return practice in paddy soils while the effect will vary among soil types due to differentiated functional microbial communities and edaphic properties.
\end{abstract}

() Higher Education Press 2020
* Corresponding author
E-mail address: zhanglm@rcees.ac.cn (L.M. Zhang)

\section{Introduction}

Soil nitrogen $(\mathrm{N})$ transformation is highly dependent on microbial processes. Microbe mediated dissimilarity reduction of nitrate $\left(\mathrm{NO}_{3}{ }^{-}\right)$such as denitrification, anaerobic ammonium oxidation (anammox) and dissimilarity nitrate reduction to 
ammonium (DNRA) frequently occur in anoxic conditions (Canfield et al., 2010; Stein and Klotz, 2016). Nitrogenous gas emission via denitrification and anammox are the main $\mathrm{N}$ loss pathways across soil and aquatic ecosystems (Salk et al., 2017). In contrast, DNRA is beneficial to $N$ retention and immobilization in $\mathrm{N}$ deficient environments since the relatively highly mobile $\mathrm{NO}_{3}{ }^{-}$and nitrite $\left(\mathrm{NO}_{2}{ }^{-}\right)$are eventually reduced to the bioavailable and less mobile ammonium $\left(\mathrm{NH}_{4}{ }^{+}\right)$in this pathway (An and Gardner, 2002). It is therefore critical to understand the occurrence and influential factors of DNRA in soil ecosystems.

Active DNRA has been widely detected in anoxic environments such as marine sediments (An and Gardner, 2002; Dong et al., 2009; Bohlen et al., 2011; Cheng et al., 2016; Reyes et al., 2017), wetlands and floodplains of terrestrial habitats (Gao et al., 2017; Jones et al., 2017). DNRA activity might be affected by multiple environmental factors such as soil redox, salinity, carbon to nitrogen ratio $(\mathrm{C} / \mathrm{N})$ and carbon to $\mathrm{NO}_{3}{ }^{-}$ratio $\left(\mathrm{C} / \mathrm{NO}_{3}{ }^{-}\right)$(Giblin et al., 2010; Lu et al., 2013; Hardison et al., 2015; Minick et al., 2016; Robertson et al., 2016; van den Berg et al., 2016; Zhou et al., 2017). Among these influential factors, $\mathrm{C} / \mathrm{N}$ and $\mathrm{C} / \mathrm{NO}_{3}{ }^{-}$are considered as the controlling factors regulating the occurrence of DNRA and denitrification, since microbes involved in the two processes usually compete for available carbon sources as electron donors and for $\mathrm{NO}_{3}{ }^{-}$as electron acceptors (Strohm et al., 2007; van den Berg et al., 2017). For instance, studies based on laboratory cultures suggested that DNRA bacteria favored conditions with excess electron donors but less electron acceptors, i.e., relatively higher $\mathrm{C} / \mathrm{N}$ and $\mathrm{C} \mathrm{NO}_{3}{ }^{-}$, while denitrifiers favored opposite conditions (Yoon et al., 2015; van den Berg et al., 2016, 2017). Field study in wetlands also indicated that denitrification was mainly limited by the supply of nitrate while DNRA was more sensitive to the increase of $\mathrm{C} /$ $\mathrm{NO}_{3}{ }^{-}$(Rahman et al., 2019). Similar observations were recorded in coastal sediments, lake/river sediments and constructed wetlands for wastewater treatment in which DNRA activity increased with $\mathrm{C} / \mathrm{N}$ or $\mathrm{C} / \mathrm{NO}_{3}{ }^{-}$(Hardison et al., 2015; Chutivisut et al., 2018; Li et al., 2019b; Pang and Ji, 2019). In contrast, less knowledge has been obtained on the DNRA in paddy soil ecosystems which possessed similar habitats as wetlands.

Paddy soils account for a large proportion of agricultural area in China. The frequent waterlog management in rice paddy fields provides favorable conditions for DNRA processes such as anoxic and low redox potential. It has been reported that DNRA rates varied from 3.06 to 10.40 $\mathrm{mg} \mathrm{N} \mathrm{kg}^{-1}$ dry soil d $\mathrm{d}^{-1}$ in cattle waste fertilized paddy soils (Lu et al., 2012). Similarly, Shan and his colleagues (2016) found that the DNRA rates ranged between 2.37 to 8.31 nmol $\mathrm{N} \mathrm{g}^{-1} \mathrm{~h}^{-1}$ in 11 typical Chinese paddy soils, and was closely related to the ratio of $\mathrm{C} / \mathrm{N}$ and the ratio of extractable organic carbon to $\mathrm{NO}_{3}{ }^{-}$concentrations. Moreover, paddy soils are relatively rich in carbon stock due to low mineralization rates under waterlogged condition, and high organic matter input via fertilization, plant residues and root exudates (Guo and Lin, 2001; Liu et al., 2019; Pandey et al., 2019). In addition, crop residues such as straw incorporation are widely applied in paddy soil fields to improve soil quality and fertility in China. It has been suggested that straw returning in paddy soil can remarkably enhance soil organic carbon stock and has distinct effects on greenhouse emission and soil microbial community through altering soil physical condition and soil C/N (Yan et al., 2013; Lu et al., 2015; Wang et al., 2018a; Wu et al., 2018; Yao et al., 2018). However, the influence of straw returning on DNRA process is rarely estimated. Furthermore, some recent studies showed that increased $\mathrm{N}$ fertilizer application in paddy soils could weaken the functional potential and decrease the abundance of DNRA microbes (Friedl et al., 2018; Pandey et al., 2018; Pandey et al., 2019). All these suggested that DNRA is a nonnegligible nitrate reduction pathway in rice cultivation agricultural soils, while fertilization regime, particular the carbon and nitrogen input, may greatly influence the process and the performance of related functional microbes.

Highly diverse microorganisms, including heterotrophic and chemolithoautotrophic microbes, are involved in DNRA process (Giblin et al., 2010; Pang and Ji, 2019; Rahman et al., 2019). Though the biomarker genes covering all DNRA functional microbes are still not available (Mohan et al., 2004), the PCR primer set targeting on nrfA gene, encoding the nitrite reductase which catalyzes the second step of DNRA process, has been developed (Kraft et al., 2011; Welsh et al., 2014). The study based on this primer set suggested that the $\operatorname{nrfA}$ gene could be found in diverse groups of bacteria including Proteobacteria, Planctomycetes, Firmicutes, Bacteroides, Verrucomicrobia, Acidobacteria and Chloroflexi, and that community composition of nrfA gene-container greatly varied among different habitats (Welsh et al., 2014). More subsequent studies in diverse habitats of aquatic ecosystems such as freshwater and wetland sediments also demonstrated that organic carbon, $\mathrm{C} / \mathrm{N}$ and $\mathrm{C} / \mathrm{NO}_{3}{ }^{-}$were crucial factors determining the community and abundance of DNRA microbes, similar to that of DNRA rates (Bu et al., 2017; Li et al., 2019a, 2019b; Palacin-Lizarbe et al., 2019; Pang and Ji, 2019). It is therefore possible to characterize the community composition and abundance of functional microbes involved in DNRA process by targeting on nrfA gene.

Therefore, in this study, a two-year pot experiment with low and high level of straw incorporation in two rice paddy soil types was established. We evaluated the DNRA rates using ${ }^{15} \mathrm{~N}$ tracer technique, and quantified the abundance of $n r f A$ genes at DNA and cDNA level, and identified active nrfA gene-container by MiSeq sequencing for nrfA genes transcript, with the aims to (1) evaluate the effects of straw amendment on DNRA process and the growth and transcription activity of DNRA microbes in paddy soils; (2) to broaden the taxonomy and diversity of DNRA bacteria in soils and identify the active microbes involved in DNRA process and their correlation with DNRA activity in paddy soils. 


\section{Materials and methods}

\subsection{Setup of pot experiment and soil sampling}

The paddy soil used for the pot experiment was originally collected from two paddy rice production areas in Binhai $(\mathrm{BH}$, $119.84^{\circ} \mathrm{E}, 34.01^{\circ} \mathrm{N}$ ) of Jiangsu Province and Taoyuan (TY, $111.48^{\circ} \mathrm{E}, 28.90^{\circ} \mathrm{N}$ ) of Hunan Province of China. The BH soil was classified as Inceptisol, and the TY soil as Ultisol according to the USDA Taxonomy, with $\mathrm{pH}$ at 7.6 and 5.7, respectively.

A two-year outdoor pot experiment was set up in 2016 as previously described (Wang et al., 2018b), including three treatments: (1) no rice straw addition (S0), (2) $0.33 \%$ (w:w) straw addition (S1) and (3) $0.66 \%$ (w:w) straw addition (S2). Briefly, three replicate pots were included for each treatment and each pot contained $10 \mathrm{~kg}$ of soils (dry weight). Before flooding, phosphorus $(\mathrm{P})$ and potassium $(\mathrm{K})$ fertilizers were applied as basal fertilizers at $90 \mathrm{~kg} \mathrm{ha}^{-1} \mathrm{P}_{2} \mathrm{O}_{5}$ and $180 \mathrm{~kg} \mathrm{ha}^{-1}$ $\mathrm{K}_{2} \mathrm{O}$, and rice straw were ground into powder and mixed thoroughly with soils. After the soils were flooded for 10 days, rice seedlings were transplanted to each pot and $\mathrm{N}$ fertilizers (urea) were applied at $72 \mathrm{~kg} \mathrm{ha}^{-1}$, and the remaining $\mathrm{N}$ fertilizers (108 $\left.\mathrm{kg} \mathrm{ha}^{-1}\right)$ were applied at rice tillering stage (day $60)$. Soil samples were collected in the depth of $0-5$ and 15 $20 \mathrm{~cm}$ at day 18 , day 58 and day 120 after rice seedlings were transplanted. Samples were stored under $4^{\circ} \mathrm{C}$ and $-80^{\circ} \mathrm{C}$ for soil physiochemical analysis and DNA extraction, respectively.

After the first rice growing season in 2016, the pots were preserved in situ and covered with tarpaulins during winter. In spring 2017, the pots were flooded for 1 month before the straw and fertilizer application. The fertilizer regimes in 2017 were same as that in 2016, except that one extra treatment (NO) which received the same $P$ and $K$ fertilization and $0.66 \%$ (w:w) straw addition but no nitrogen fertilization was included, in order to construct a wider $\mathrm{C} / \mathrm{N}$ gradient and determine the effect of nitrogen input on DNRA. The results from the first year showed that $n r f A$ gene abundance was more abundant in surface than subsurface layer and peaked in the early stage after straw amendment (as shown in 3.2). We thus only collected surface soil samples $(0-10 \mathrm{~cm})$ at day 7 after seedling transplantation for DNRA rate determination and mRNA analysis in 2017 . Samples were stored under $4^{\circ} \mathrm{C}$ for further slurry incubation experiment and physiochemical properties determination.

\subsection{Measurement of soil physiochemical properties}

Soil $\mathrm{pH}$ was determined in a soil:water of 1:2.5 (w/w). Soil $\mathrm{NH}_{4}{ }^{+} \mathrm{N}$ and $\mathrm{NO}_{3}{ }^{-} \mathrm{N}$ were extracted with $1 \mathrm{M} \mathrm{KCl}$ and then determined using a continuous flow analytical system (AA3, SEAL analytical, Germany). Soil total carbon (TC) and total nitrogen (TN) were measured by an Elemental analyzer (Vario
EL III-Elementar, Germany). Soil Eh values were measured in situ using soil Eh meter PRN-41 (DKK, TOA, Tokyo, Japan).

\subsection{Determination of DNRA rates using ${ }^{15} \mathrm{~N}$ tracer technique}

\subsubsection{Slurry incubation of paddy soils from pot experiment}

Soil samples from 2017 were subjected to a slurry incubation experiment with ${ }^{15} \mathrm{NO}_{3}{ }^{-}$addition to determine the rate of DNRA. Approximately $6.5 \mathrm{~g}$ freshly sampled soils from the pots were weighed into $100 \mathrm{~mL}$ glass serum bottles and soil slurries were made by adding sterile deionized water to a unified flooding degree under $2 \mathrm{~cm}$ depth layer. The bottles were sealed with rubber septa and aluminum crimp caps, and the headspace of the bottles was vacuumed then purged with $\mathrm{N}_{2}$ to remain anaerobic circumstances. The bottles were preincubated in darkness at $25^{\circ} \mathrm{C}$ for $24 \mathrm{~h}$ to consume the background $\mathrm{NO}_{3}{ }^{-}$, and then purged with $\mathrm{N}_{2}$ again to remove the residual oxygen released from the slurries. The ${ }^{15} \mathrm{~N}-\mathrm{KNO}_{3}$ with a final concentration of $100 \mu \mathrm{M}-{ }^{15} \mathrm{~N}$ was injected into each bottle as the source of $\mathrm{NO}_{3}^{-}$.

$\mathrm{KCl}$ solution was added to the bottles with a final concentration at $2 \mathrm{M}$ at $0 \mathrm{~h}$ (initiating time) and $24 \mathrm{~h}$ (ending time) respectively to block the reaction and to extract $\mathrm{NH}_{4}{ }^{+}$. The concentration of $\mathrm{NH}_{4}{ }^{+}$was measured by the continuous flow analytical system (AA3, SEAL analytical, Germany). An extra set of slurry incubation with the same treatment without $\mathrm{KCl}$ addition at $24 \mathrm{~h}$ was also conducted specifically for the molecular analysis of DNRA bacteria. At the $24 \mathrm{~h}$ time point, the slurry was collected and separately stored at $-40^{\circ} \mathrm{C}$ and $-80^{\circ} \mathrm{C}$ for further DNA and RNA extraction, respectively.

\subsubsection{Conversion of $\mathrm{NH}_{4}{ }^{+}$to $\mathrm{N}_{2} \mathrm{O}$ and gas isotope analysis}

To determine the abundance of ${ }^{15} \mathrm{~N}-\mathrm{NH}_{4}{ }^{+}$, the extracted $\mathrm{NH}_{4}{ }^{+}$ was converted to $\mathrm{N}_{2} \mathrm{O}$ using $\mathrm{MgO}$ diffusion combining with hypobromite $\left(\mathrm{BrO}^{-}\right)$oxidation-hydroxylamine $\left(\mathrm{NH}_{2} \mathrm{OH}\right)$ reduction method as described preciously by former studies (Liu et al., 2014; Zhang et al., 2015). Briefly, GF/D filter paper (Whatman, UK) for trapping $\mathrm{NH}_{4}{ }^{+}$was cut into $1 \mathrm{~cm}$ diameter disks then wrapped by Teflon tape (Sigma Aldrich, St. Louis, $\mathrm{MO}, \mathrm{USA}$ ) membrane, and $20 \mu \mathrm{L}$ of $2 \mathrm{M} \mathrm{H}_{2} \mathrm{SO}_{4}$ was added to the center of the disks. The extracted $\mathrm{NH}_{4}{ }^{+}$solution was added into $20 \mathrm{~mL}$ headspace glass vials (Chromacol, UK) and adjusted the salt concentration to $2 \mathrm{M}$ by adding $\mathrm{KCl}$. The Teflon tape wrapped filter paper disks were placed into each vial and $0.015 \mathrm{~g}$ of $\mathrm{MgO}$ was added to trap $\mathrm{NH}_{4}{ }^{+}$. The vials were then capped with rubber septa plus aluminum crimp seals and incubated at $37^{\circ} \mathrm{C}$ for 7 days on a shaker $\left(90 \mathrm{r} \mathrm{min}^{-1}\right)$.

After 7 days diffusion, the filter paper disks were collected and washed with $0.1 \mathrm{M} \mathrm{HCl}$, and then rinsed with deionized water to remove residual $\mathrm{MgO}$. The Telfon tapes were opened with a tweezer and the filter paper disks wrapped by the tapes were taken out to clean vials, and $5 \mathrm{~mL}$ deionized water was pipetted into each vial. The vials were shaken for $30 \mathrm{~min}$ to 
extract $\mathrm{NH}_{4}{ }^{+}$trapped in the fiber disks, and the concentration of $\mathrm{NH}_{4}{ }^{+}-\mathrm{N}$ was further diluted to $15 \mu \mathrm{M}$ by deionized water. Then $4 \mathrm{~mL}$ of each sample were transferred into a new vial and $0.4 \mathrm{~mL} \mathrm{BrO}^{-}$working solution was added, then the vials were shaken vigorously in order to convert $\mathrm{NH}_{4}{ }^{+}$to $\mathrm{NO}_{2}{ }^{-}$by oxidation. After standing still for $30 \mathrm{~min}, 0.05 \mathrm{~mL} \mathrm{NaAsO}{ }_{2}$ was added to deplete the excess $\mathrm{BrO}^{-}$and terminate the reaction, then $0.5 \mathrm{~mL}$ of $6 \mathrm{M} \mathrm{HCl}$ was pipetted and the vials were capped tightly with gray butyl septa and aluminum crimp seals, to generate an acidic environment in order to increase the yield of $\mathrm{N}_{2} \mathrm{O}$ in the next step. Afterward, $0.5 \mathrm{~mL}$ $\mathrm{NH}_{2} \mathrm{OH} \cdot \mathrm{HCl}$ working solution was injected into each vial by a gastight syringe and the vials were incubated in a shaker for $16 \mathrm{~h}\left(37^{\circ} \mathrm{C}, 120 \mathrm{r} \mathrm{min}^{-1}\right)$. Finally, $0.5 \mathrm{~mL}$ of $5 \mathrm{M} \mathrm{NaOH}$ was injected to each vial to stop the reaction.

Stable nitrogen isotope of the produced $\mathrm{N}_{2} \mathrm{O}$ in the headspace of the vials were analyzed by an automated PTIRMS system, which included a continuous flow IRMS (IsoPrime100, IsoPrime limited, UK) coupled with a Gilson GX-271 112-slot autosampler (Gilson, Middleton, WI, USA) and a PreCon automated trace gas pre-concentrator cryofocusing unit (Thermo Scientific, Waltham, MA, USA). The calculation of true $\delta^{15} \mathrm{~N}$ values for $\mathrm{NH}_{4}^{+}$was based on previous description by Zhang and colleagues (2015). The potential rate of DNRA was calculated by the following equation:

$$
\mathrm{R}_{\text {DNRA }}=\frac{\left[{ }^{15} \mathrm{NH}_{4}^{+}\right]_{24 \mathrm{~h}}-\left[{ }^{15} \mathrm{NH}_{4}^{+}\right]_{0 \mathrm{~h}}}{T}
$$

where $\left[{ }^{15} \mathrm{NH}_{4}^{+}\right]_{24 h}$ and $\left[{ }^{15} \mathrm{NH}_{4}^{+}\right]_{\text {on }}$ is the concentration of ${ }^{15} \mathrm{NH}_{4}{ }^{+} \mathrm{N}$ in the final and initial samples of the slurry incubation experiment, and $T$ is the incubation time.

2.4 Extraction of soil total DNA and RNA and reverse transcription

Soil total DNA from pot experiment of 2016 and slurry incubation of 2017 was extracted from $0.25 \mathrm{~g}$ slurry with the DNeasy PowerSoil DNA Isolation kit (QIAGEN, Germany) as per the manufacturer's instructions. Soil total RNA was extracted from $2 \mathrm{~g}$ slurry samples of 2017 using RNeasy PowerSoil Total RNA Kit (QIAGEN, Germany). The procedure was carried out following the manufacture's protocols. The extracted DNA and RNA were checked with gel-electrophoresis and stored at $-40^{\circ} \mathrm{C}$ and $-80^{\circ} \mathrm{C}$ respectively for further analysis. Residual DNA in the RNA samples were digested with RQ1 RNase-Free DNase (TaKaRa, Japan), and the absence of DNA in DNase-treated RNA templates was checked by PCR amplification with the bacterial 16S rRNA gene primers $27 F / 1492 R$ before the reverse transcription of RNA. The cDNA synthesis was performed with SuperScript III Reverse Transcriptase (Thermo Fischer Scientifc, USA) with random hexamer primers at a concentration of $0.1 \mathrm{mM}$ according to the manufacture's protocol. For reverse transcript (RT) reaction, a control containing RNA template and $\mathrm{RT}$ reagents without reverse transcriptase and another control containing no template were included to ensure there was no DNA and reagent contamination.

\subsection{Quantitative PCR (qPCR) for nrfA genes at DNA and RNA level}

Analysis of qPCR was conducted to determine the abundance and transcription activity of nrfA genes with the primer set nrfAF2aw (5'-CARTGYCAYGTBGARTA-3') and nrfAR1 (5'TWNGGCATRTGRCARTC-3') (Welsh et al., 2014). The mixture for $\mathrm{qPCR}$ reaction contained $12.5 \mu \mathrm{L}$ of $2 \times$ SsoAdvanced Universal SYBR Green Supermix (Bio-Rad, USA), $1 \mu \mathrm{L}$ of template, $10 \mu \mathrm{M}$ each primer and $9.5 \mu \mathrm{L}$ of sterilized deionized water. The thermocycling conditions were as follow: $95^{\circ} \mathrm{C}$ for $5 \mathrm{~min}$, followed by 40 cycles of $95^{\circ} \mathrm{C}$ for 30 $\mathrm{s}, 53^{\circ} \mathrm{C}$ for $30 \mathrm{~s}, 72^{\circ} \mathrm{C}$ for $20 \mathrm{~s}$, and plate was read at $83^{\circ} \mathrm{C}$ for $15 \mathrm{~s}$ to produce the melting curve.

2.6 Illumina sequencing of nrfA genes and bioinformation analysis

To characterize the diversity and community composition of active DNRA bacteria, the nrfA gene amplicons amplified with above mentioned primers were subjected to Illumina MiSeq platform sequencing. The PCR reaction mixture for amplicons contained $25 \mu \mathrm{L}$ of $2 \times$ TaKaRa Premix (TaKaRa Bio Inc., Shiga, Japan), $2 \mu \mathrm{L}$ of DNA or CDNA template, $10 \mu \mathrm{M}$ each primer and $21 \mu \mathrm{L}$ of sterilized deionized water. The thermocycling protocol was $95^{\circ} \mathrm{C}$ for $5 \mathrm{~min}$, followed by 35 cycles of $95^{\circ} \mathrm{C}$ for $30 \mathrm{~s}, 53^{\circ} \mathrm{C}$ for $30 \mathrm{~s}, 72^{\circ} \mathrm{C}$ for $20 \mathrm{~s}$, and a final extension of $10 \mathrm{~min}$ at $72^{\circ} \mathrm{C}$. The amplified fragments were added with lllumina adaptors and specific barcode sequences at the $5^{\prime}$ and $3^{\prime}$ ends. The obtained raw reads of nrfA genes were deposited to the NCBI SRA database (Accession No.: PRJNA597679). The QIIME software (version 2.0, http:// qiime.org/) was utilized for assembling and filtering of raw sequences, further OTUs definition according to a similarity of 97\% (Bu et al., 2017), and then a-diversity index calculation. The identification and selection of representative sequences of the nrfA OTUs were conducted according to the published nrfA sequences in the Fungene database (http://fungene. cme.msu.edu/).

The most abundant 100 nrfA gene transcript OTUs were chosen and translated into the amino sequences (NrfA) with MEGA software (version 5.0), and aligned with MUSCLE. The phylogenetic tree of NrfA amino sequences was constructed in MEGA by using the neighbor-joining method with 1000 bootstraps (Kumar et al., 2008). Reference NrfA sequences from known bacterial strains with verified DNRA function were obtained from the FunGene websites (http://fungene.cme. msu.edu/) based on Welsh and colleague's work (2014), other reference sequences were obtained from NCBI by BLAST search. The representative sequences of $n r f A$ gene transcripts used in phylogenetic tree construction in this study were deposited in GenBank database and assigned accession numbers from MT133359 to MT133458. 


\subsection{Statistical analysis}

SPSS 19 (IBM, USA) was used for the Spearman's correlation analyses between DNRA rates, abundance and soil properties, and one-way ANOVA test for the difference in DNRA rates and nrfA gene abundance among treatments. Detrended correspondence analysis (DCA) for microbial community structure and Mantel test for relationship between microbial community structure and environmental factors were conducted by utilizing vegan package in $\mathrm{R}$ software.

\section{Results}

\subsection{Soil physiochemical properties during rice growing periods}

Soil properties in 2016 have been presented in our previous work (Table S1) (Wang et al., 2018b), and the results of 2017 were similar to that of 2016 . In 2017 , soil pH ranged between 8.4 to 8.6 in the $\mathrm{BH}$ soil (Inceptisol) with no significant difference among the treatments, while $\mathrm{pH}$ in the TY soil was significantly increased by $0.8-1.0$ unit after one-year rice plantation, compared with the newly flooded N0 treatment $(\mathrm{pH}$ at 6.4) in 2017 (Table 1). For both soil types, ammonium concentration decreased following the order $\mathrm{S} 0>\mathrm{S} 1>\mathrm{S} 2>$ $\mathrm{NO}$, and nitrate concentration showed no significant difference among four treatments. Soil Eh was significantly lower in S0 treatment $(-36.67 \mathrm{mV})$ than in $\mathrm{S} 1, \mathrm{~S} 2$ and $\mathrm{N} 0$ treatments $(9.78-16.22 \mathrm{mV})$ in the $\mathrm{BH}$ soil, while it was 4-fold lower in N0 treatment $(19.33 \mathrm{mV})$ than S0, S1 and S2 treatments $(80.22$ $94.22 \mathrm{mV}$ ) in the TY soil (Table 1). For both $\mathrm{BH}$ and TY soil, straw addition enhanced soil DOC and TC contents, with a significantly higher DOC value in S2 treatment (123.27 and $210.68 \mathrm{mg} \mathrm{kg}^{-1}$ for the $\mathrm{BH}$ and TY soil, respectively) than in S0 treatment $\left(80.75\right.$ and $157.86 \mathrm{mg} \mathrm{kg}^{-1}$ for the $\mathrm{BH}$ and TY soil, respectively) (Table 1 ). Soil total $\mathrm{C} / \mathrm{N}$ ranged between 17.86 and 19.15 in the $\mathrm{BH}$ soil and between 9.49 and 10.54 in the TY soil, and was lowest in NO treatment of $\mathrm{BH}$ soil and SO treatment of TY soil within each soil type (Table 1). Soil $\mathrm{C} / \mathrm{NO}_{3}{ }^{-}$ratio showed an increasing trend with the straw addition level in both soils, with $\log _{10}\left(\mathrm{C} / \mathrm{NO}_{3}{ }^{-}\right)$values ranging between 3.70 and 3.85 (Table 1).

3.2 The abundance of $n r f A$ genes in soils during the first rice growth season

Soil samples collected from rice pot in 2016 were subjected to qPCR for quantitative estimation of $n r f A$ gene abundance (Fig. 1). Generally, the copy numbers of nrfA gene ranged between $2.84 \times 10^{9}-6.50 \times 10^{10} \mathrm{~g}^{-1}$ dry soil in the $\mathrm{BH}$ soil, and between $2.77 \times 10^{9}-3.46 \times 10^{10} \mathrm{~g}^{-1}$ dry soil in the TY soil (Fig. 1). Moreover, the copy numbers of nrfA gene were relatively higher in the surface than in subsurface soils, and were approximately 10 -fold higher at day 18 than at day 58 and 120 in both soils (Fig. 1). For the $\mathrm{BH}$ soil, the $n r f A$ genes in both surface and subsurface layers of S2 treatment were significantly more abundant than those in S1 and S0 treatments in the early stage (day 18), but showed no significant difference among treatments in the later rice growth stages at day 58 and day $120(P<0.05$, Fig. 1). For the TY soil, nrfA gene abundance showed an increasing trend with the straw incorporation in surface soils though the difference was not significant $(P>0.05$, Fig. 1). All these suggested that straw incorporation promoted the abundance of DNRA microbes, particularly in the early stage of straw amendment (Fig. 1). Spearman correlation analysis indicated that abundance of $n r f A$ gene was positively correlated to soil TC $(r=0.22, P<0.05)$ and TN $(r=0.24, P<0.05)$.

3.3 DNRA rates in soils from pot experiment in second rice growth season

Quantitative PCR results from the first rice season showed that straw significantly increased the abundance of DNRA microbes in the early stage of rice growth. Therefore, soil samples collected at day 7 after transplantation were subjected to ${ }^{15} \mathrm{~N}-\mathrm{NO}_{3}{ }^{-}$slurry incubation (24 samples covering 2 soil types, 4 treatments and 3 replicates) for DNRA rate determination in the second year. The results of ${ }^{15} \mathrm{~N}$ analysis showed that straw amendment increased DNRA rates in these paddy soils. Specifically, DNRA rates in S2 treatment $\left(2.73 \mathrm{nmol} \mathrm{N} \mathrm{g} \mathrm{h}^{-1}\right)$ were significantly higher than that in the control (S0, $\left.0.74 \mathrm{nmol} \mathrm{N} \mathrm{g}^{-1} \mathrm{~h}^{-1}\right)$ in the $\mathrm{BH}$ soil $(P<0.05$, Fig. 2), and were significantly higher in $S 1$ treatments (1.76 $\left.\mathrm{nmol} \mathrm{N} \mathrm{g}^{-1} \mathrm{~h}^{-1}\right)$ than in S0 $\left(0.24 \mathrm{nmol} \mathrm{N} \mathrm{g}{ }^{-1} \mathrm{~h}^{-1}\right)$ and NO $(0.53$ nmol $\left.\mathrm{N} \mathrm{g}^{-1} \mathrm{~h}^{-1}\right)$ treatments in the TY soil $(P<0.05$, Fig. 2). DNRA rates were approximately 2.3 and 3.7 folds higher in S1 and $\mathrm{S} 2$ treatments than in $\mathrm{S} 0$ in the $\mathrm{BH}$ soil, and 4.8-7.3 folds higher in S1 and S2 treatments than in S0 in the TY soil. In both soils, the DNRA rates in the treatments without nitrogen fertilizer (N0) were relatively lower than S1 and S2 but higher than in S0 treatment (Fig. 2). Spearman correlation analysis indicated that DNRA rates significantly correlated to soil $\mathrm{pH}$ ( $r=0.43, P<0.05)$, TC $(r=0.46, P<0.05), \mathrm{C} / \mathrm{N}(r=0.43$, $P<0.05)$ and $\mathrm{C} / \mathrm{NO}_{3}{ }^{-}(r=0.64, P<0.01)$ (Table 2).

3.4 The abundance, transcription activity and diversity of $n r f A$ genes in slurry incubation soils

Soil samples from the slurry incubation were further subjected to $\mathrm{qPCR}$ and RT-qPCR analysis for quantifying the abundance and transcriptional activity of nrfA gene. The results showed that the nrfA gene abundance was relatively higher in the $\mathrm{BH}$ soil than in the TY soil at both DNA and RNA levels, which was consistent with the observation at DNA level in the first season. For the $\mathrm{BH}$ soil, the nrfA gene abundance was significantly higher in S1, S2 and N0 treatments $\left(4.64 \times 10^{9}-\right.$ $5.69 \times 10^{9}$ copy g $^{-1}$ dry soil $)$ than in S0 $\left(2.13 \times 10^{9}\right.$ copy g $^{-1}$ dry soil) $(P<0.05$, Fig. 3$)$. The transcriptional activity of $n r f A$ gene showed similar trends as gene abundance at DNA level, which was significantly improved by straw incorporation. Particularly, nrfA gene transcripts were significantly higher in three straw addition treatments (S1, S2 and N0, $5.01 \times 10^{6}$ $6.22 \times 10^{6}$ copy g $^{-1}$ dry soil) than in the straw-free S0 treatment 
Table 1 Soil physiochemical properties one week after seedling transplantation in the pot experiment in 2017.

\begin{tabular}{|c|c|c|c|c|c|c|c|c|c|c|}
\hline $\begin{array}{l}\text { Soil } \\
\text { type }\end{array}$ & Treatments & $\mathrm{pH}$ & $E h(\mathrm{mV})$ & $\begin{array}{l}\text { DOC } \\
(\mathrm{mg} \mathrm{kg})^{-1}\end{array}$ & $\begin{array}{l}\mathrm{NH}_{4}{ }^{+} \\
(\mathrm{mg} \mathrm{kg})^{-1}\end{array}$ & $\begin{array}{l}\mathrm{NO}_{3}^{-} \\
(\mathrm{mg} \mathrm{kg})^{-1}\end{array}$ & $\begin{array}{l}\text { TN } \\
(\mathrm{g} \mathrm{kg})^{-1}\end{array}$ & $\begin{array}{l}\text { TC } \\
(\mathrm{g} \mathrm{kg})^{-1}\end{array}$ & $\mathrm{C} / \mathrm{N}$ & $\log _{10}\left(\mathrm{C} / \mathrm{NO}_{3}{ }^{-}\right)$ \\
\hline \multirow[t]{4}{*}{$\overline{\mathrm{BH}}$} & SO & $\begin{array}{l}8.6 \pm \\
0.07^{\mathrm{A}}\end{array}$ & $\begin{array}{l}-36.67 \pm \\
5.64^{\mathrm{B}}\end{array}$ & $\begin{array}{l}80.75 \pm \\
3.67^{\mathrm{C}}\end{array}$ & $\begin{array}{l}43.14 \pm \\
6.21^{\mathrm{A}}\end{array}$ & $\begin{array}{l}0.97 \pm \\
0.86^{\mathrm{A}}\end{array}$ & $\begin{array}{l}1.18 \pm \\
0.02^{\mathrm{A}}\end{array}$ & $\begin{array}{l}22.09 \pm \\
0.19^{\mathrm{A}}\end{array}$ & $\begin{array}{l}18.67 \pm \\
0.29^{\mathrm{AB}}\end{array}$ & $\begin{array}{l}3.73 \pm \\
0.06^{\mathrm{A}}\end{array}$ \\
\hline & S1 & $\begin{array}{l}8.6 \pm \\
0.02^{\mathrm{A}}\end{array}$ & $\begin{array}{l}10.78 \pm \\
6.37^{\mathrm{A}}\end{array}$ & $\begin{array}{l}107.50 \pm \\
7.57^{\mathrm{BC}}\end{array}$ & $\begin{array}{l}37.36 \pm \\
8.90^{\mathrm{AB}}\end{array}$ & $\begin{array}{l}2.30 \pm \\
0.52^{\mathrm{A}}\end{array}$ & $\begin{array}{l}1.45 \pm \\
0.08^{\mathrm{A}}\end{array}$ & $\begin{array}{l}25.90 \pm \\
1.27^{\mathrm{A}}\end{array}$ & $\begin{array}{l}17.86 \pm \\
0.08^{\mathrm{B}}\end{array}$ & $\begin{array}{l}3.83 \pm \\
0.02^{\mathrm{A}}\end{array}$ \\
\hline & S2 & $\begin{array}{l}8.4 \pm \\
0.06^{A}\end{array}$ & $\begin{array}{l}16.22 \pm \\
8.70^{\mathrm{A}}\end{array}$ & $\begin{array}{l}123.27 \pm \\
5.09^{\mathrm{B}}\end{array}$ & $\begin{array}{l}21.61 \pm \\
2.89^{\mathrm{BC}}\end{array}$ & $\begin{array}{l}1.42 \pm \\
0.37^{\mathrm{A}}\end{array}$ & $\begin{array}{l}1.41 \pm \\
0.05^{\mathrm{A}}\end{array}$ & $\begin{array}{l}25.59 \pm \\
1.00^{\mathrm{A}}\end{array}$ & $\begin{array}{l}18.08 \pm \\
0.08^{\mathrm{B}}\end{array}$ & $\begin{array}{l}3.85 \pm \\
0.02^{\mathrm{A}}\end{array}$ \\
\hline & No & $\begin{array}{l}8.6 \pm \\
0.03^{A}\end{array}$ & $\begin{array}{l}9.78 \pm \\
8.18^{A}\end{array}$ & $\begin{array}{l}227.05 \pm \\
19.09^{A}\end{array}$ & $\begin{array}{l}7.49 \pm \\
0.39^{\mathrm{C}}\end{array}$ & $\begin{array}{l}1.59 \pm \\
0.37^{\mathrm{A}}\end{array}$ & $\begin{array}{l}1.19_{ \pm}^{ \pm} \\
0.14^{\mathrm{A}}\end{array}$ & $\begin{array}{l}22.67 \pm \\
1.93^{\mathrm{A}}\end{array}$ & $\begin{array}{l}19.15 \pm \\
0.54^{\mathrm{A}}\end{array}$ & $\begin{array}{l}3.58 \pm \\
0.19^{A}\end{array}$ \\
\hline \multirow[t]{4}{*}{ TY } & So & $\begin{array}{l}7.4 \pm \\
0.1^{\mathrm{a}}\end{array}$ & $\begin{array}{l}80.22 \pm \\
4.59^{a}\end{array}$ & $\begin{array}{l}157.86 \pm \\
3.08^{\mathrm{c}}\end{array}$ & $\begin{array}{l}92.61 \pm \\
9.93^{\mathrm{a}}\end{array}$ & $\begin{array}{l}1.47 \pm \\
0.41^{\mathrm{a}}\end{array}$ & $\begin{array}{l}1.98 \pm \\
0.02^{\mathrm{a}}\end{array}$ & $\begin{array}{l}18.83 \pm \\
0.39^{b}\end{array}$ & $\begin{array}{l}9.49 \pm \\
0.09^{c}\end{array}$ & $\begin{array}{l}3.70 \pm \\
0.02^{\mathrm{a}}\end{array}$ \\
\hline & S1 & $\begin{array}{l}7.2 \pm \\
0.05^{a}\end{array}$ & $\begin{array}{l}94.22 \pm \\
4.39^{\mathrm{a}}\end{array}$ & $\begin{array}{l}189.02 \pm \\
3.05^{\mathrm{ab}}\end{array}$ & $\begin{array}{l}85.89 \pm \\
8.82^{\mathrm{a}}\end{array}$ & $\begin{array}{l}1.63 \pm \\
0.30^{\mathrm{a}}\end{array}$ & $\begin{array}{l}2.02 \pm \\
0.02^{\mathrm{a}}\end{array}$ & $\begin{array}{l}20.94 \pm \\
0.19^{a}\end{array}$ & $\begin{array}{l}10.35 \pm \\
0.03^{\mathrm{ab}}\end{array}$ & $\begin{array}{l}3.72 \pm \\
0.03^{\mathrm{a}}\end{array}$ \\
\hline & S2 & $\begin{array}{l}7.2 \pm \\
0.03^{a}\end{array}$ & $\begin{array}{l}81.89 \pm \\
6.17^{a}\end{array}$ & $\begin{array}{l}210.68 \pm \\
6.05^{a}\end{array}$ & $\begin{array}{l}48.26 \pm \\
8.50^{\mathrm{b}}\end{array}$ & $\begin{array}{l}1.06 \pm \\
0.33^{\mathrm{a}}\end{array}$ & $\begin{array}{l}2.02 \pm \\
0.03^{a}\end{array}$ & $\begin{array}{l}21.32 \pm \\
0.48^{a}\end{array}$ & $\begin{array}{l}10.54 \pm \\
0.08^{\mathrm{a}}\end{array}$ & $\begin{array}{l}3.73 \pm \\
0.03^{\mathrm{a}}\end{array}$ \\
\hline & No & $\begin{array}{l}6.4 \pm \\
0.1^{\mathrm{b}}\end{array}$ & $\begin{array}{l}19.33 \pm \\
2.84^{\mathrm{b}}\end{array}$ & $\begin{array}{l}176.61 \pm \\
14.4^{\mathrm{bc}}\end{array}$ & $\begin{array}{l}18.23 \pm \\
0.39^{c}\end{array}$ & $\begin{array}{l}1.05 \pm \\
0.37^{\mathrm{a}}\end{array}$ & $\begin{array}{l}1.87 \pm \\
0.01^{\mathrm{a}}\end{array}$ & $\begin{array}{l}18.92 \pm \\
0.27^{b}\end{array}$ & $\begin{array}{l}10.14 \pm \\
0.54^{\mathrm{b}}\end{array}$ & $\begin{array}{l}3.71 \pm \\
0.03^{\mathrm{a}}\end{array}$ \\
\hline
\end{tabular}

Note: BH means soil from Binhai (Inceptisol), and TY means soil from Taoyuan (Ultisol). The capital letter and lowercase behind the numbers indicate significant differences within the $\mathrm{BH}$ soil and the TY soil, respectively.

$\left(2.75 \times 10^{6}\right.$ copy $\mathrm{g}^{-1}$ dry soil), and was more abundant in N0 than in $\mathrm{S} 1$ and $\mathrm{S} 2$ treatments $(P<0.05$, Fig. 3). For the TY soil, nrfA gene abundance was significantly lower in N0 treatment $\left(2.11 \times 10^{8}\right.$ copy g $^{-1}$ dry soil $)$ than that in other treatments, and showed no significant difference among S0, S1 and S2 treatments $\left(1.79 \times 10^{9}-2.73 \times 10^{9}\right.$ copy g $^{-1}$ dry soil) (Fig. 3$)$. Similarly, nrfA gene transcript was lowest in N0 treatment $\left(3.93 \times 10^{5}\right.$ copy $\mathrm{g}^{-1}$ dry soil) while it was significantly higher in S2 treatment $\left(1.87 \times 10^{6}\right.$ copy $^{-1}$ dry soil $)$ than that in

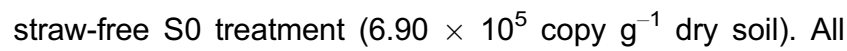
these suggested that straw incorporation markedly improved the growth and activity of nrfA gene containers in both soil types, with a greater effect on the $\mathrm{BH}$ soil.

Positive relationships were found between $n r f A$ gene abundance/transcript activity and DNRA rates $(r=0.49$ for DNA and $r=0.52$ for cDNA, $P<0.05$ ) (Table 2). Both nrfA gene abundance and transcription activity positively correlated to soil $\mathrm{pH}(r=0.66, P<0.01, r=0.75, P<0.01)$, TC $(r=$

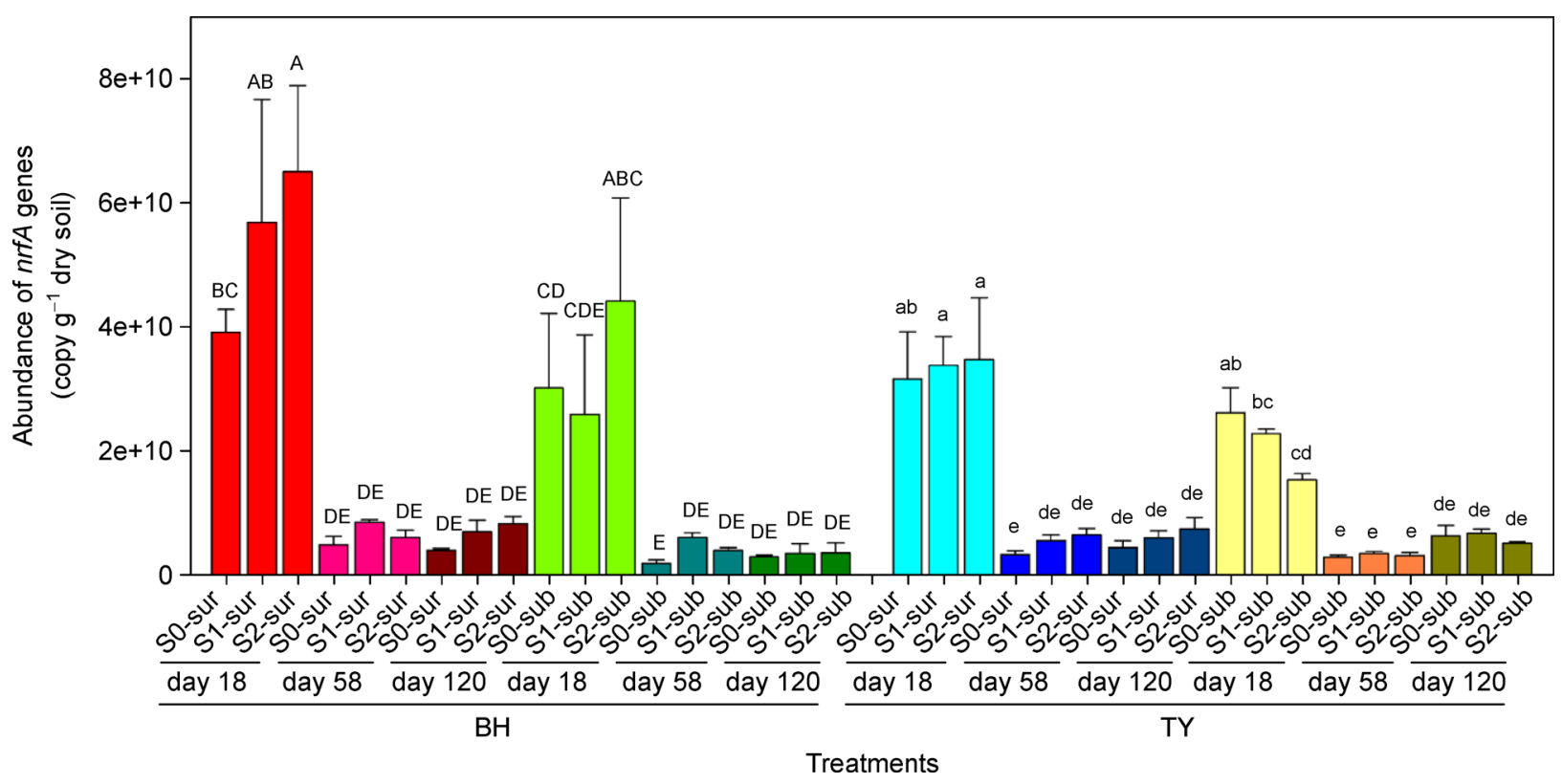

Fig. 1 Abundance of nrfA genes in two soil types over the time in 2016. "-sur" and "-sub" following treatment denote "surface" and "subsurface" layer, respectively; BH means soil from Binhai (Inceptisol), and TY means soil from Taoyuan (Ultisol). The uppercase and lowercase letters above the bars indicate significant differences within the $\mathrm{BH}$ and $\mathrm{TY}$ soils respectively by oneway ANOVA test. 


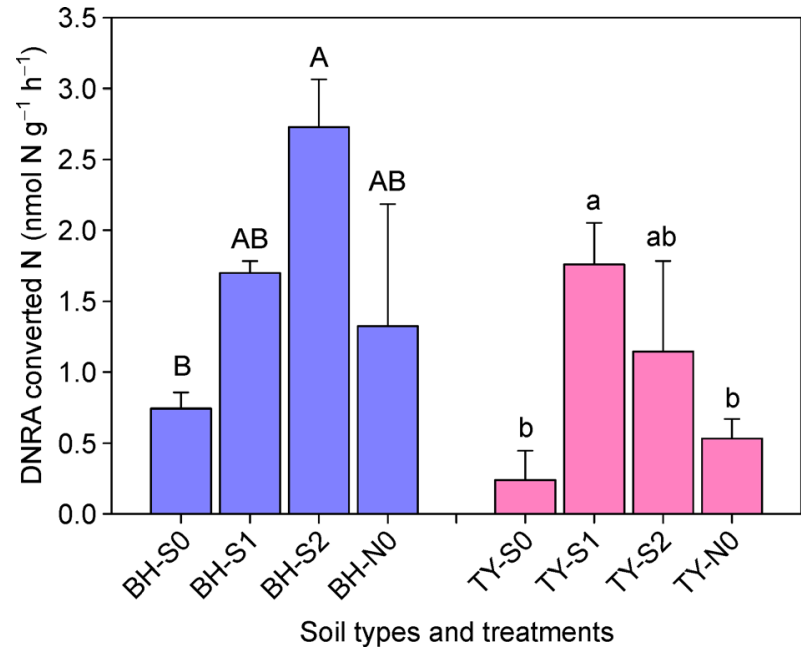

Fig. 2 DNRA rate estimated by ${ }^{15} \mathrm{NO}_{3}{ }^{-}$incubation for pot experiment soils in 2017. The uppercase and lowercase letters above the bars indicate significant differences within each soil by one-way ANOVA test.
$0.82, P<0.01, r=0.77, P<0.01), \mathrm{C} / \mathrm{N}(r=0.65, P<0.01, r=$ $0.78, P<0.01)$ and $\mathrm{C} / \mathrm{NO}_{3}{ }^{-}(r=0.63, P<0.01, r=0.58$, $P<0.01)$, but negatively correlated to total $\mathrm{N}(r=-0.42$, $P<0.05, r=-0.58, P<0.01$ ) (Table 2).

All nrfA gene transcripts from slurry incubation samples were further subjected to MiSeq sequencing. Totally, 7193 OTUs were generated after resampling with 59000 nrfA gene reads per sample. Generally, almost all $\alpha$-diversity indexes including Ace, Chao, Shannon and inverse Simpson of diversity were relatively higher in the $\mathrm{BH}$ soil than in the TY soil (Fig. S1), but showed no significant difference among treatments (Table S3). On DCA plots, the communities of active DNRA microbes were primarily separated by soil types, then by treatments within each soil type (Fig. 4). For both soil types, S0 treatment was well separated from treatments with straw addition (S1, S2 and N0) (Fig. 4). In addition, N0 treatment was also separated from $\mathrm{S} 1$ and $\mathrm{S} 2$ treatments in the TY soil (Fig. 4). All these indicated that rice straw amendment distinctly shifted the community composition of active nrfA-gene containers for both $\mathrm{BH}$ and TY soils, and nitrogen fertilization had markedly effects as well in the TY

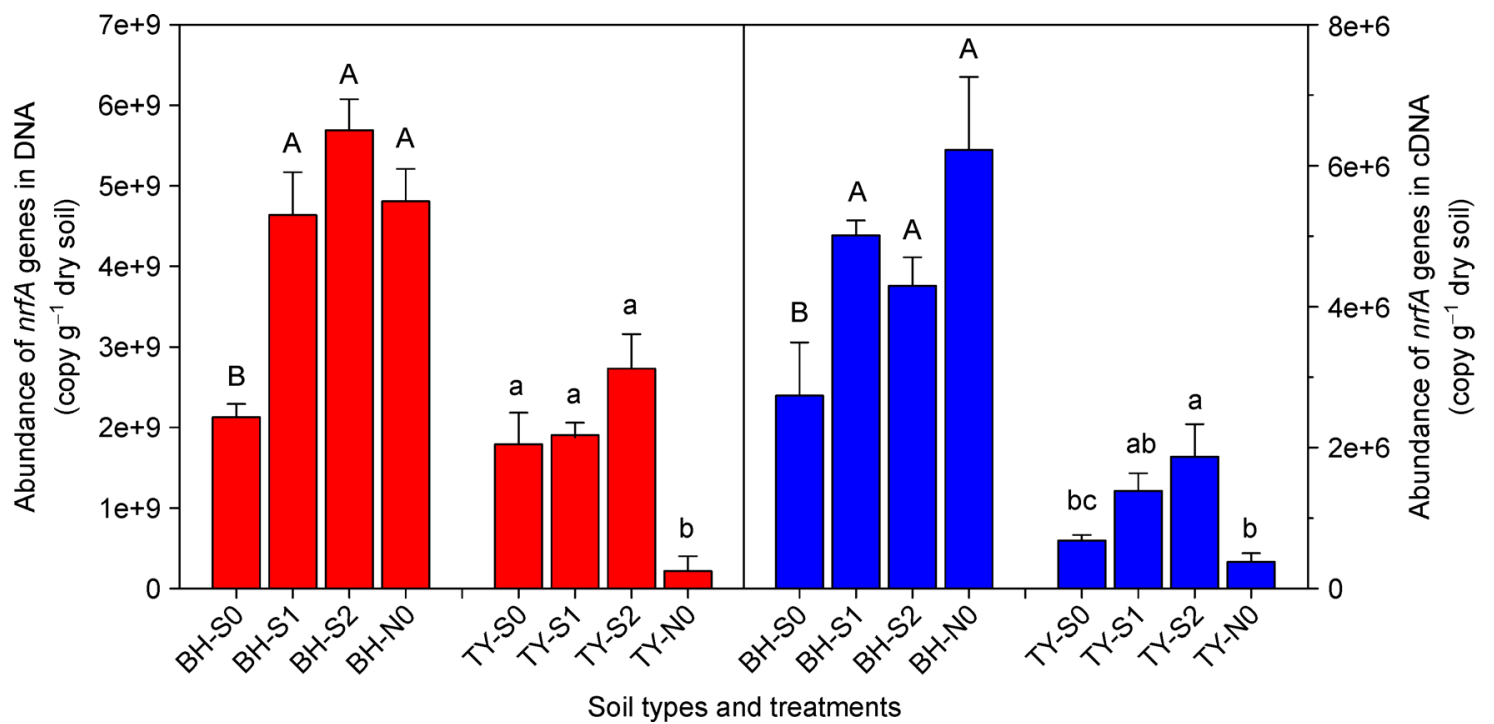

Fig. 3 Abundance of $n r f A$ genes (left) and transcript (right) in ${ }^{15} \mathrm{NO}_{3}{ }^{-}$incubation soils. The labels "A, B" and "a, b" above the bars indicate significant differences within each soil by one-way ANOVA test, and the difference was compared separately for DNA and cDNA results.

Table 2 Spearman correlations of DNRA rates, nrfA gene and transcripts abundance versus soil physiochemical parameters and diversity indexes of DNRA microbes in 2017.

\begin{tabular}{|c|c|c|c|c|c|c|c|c|c|c|c|c|c|}
\hline & $\mathrm{pH}$ & $E h$ & DOC & $\mathrm{NH}_{4}{ }^{+}$ & $\mathrm{NO}_{3}{ }^{-}$ & $\mathrm{TN}$ & $\mathrm{TC}$ & $\mathrm{C} / \mathrm{N}$ & $\mathrm{C} / \mathrm{NO}_{3}{ }^{-}$ & $\begin{array}{l}\text { nrfA in } \\
\text { RNA }\end{array}$ & $\begin{array}{l}\text { nrfA in } \\
\text { DNA }\end{array}$ & $\begin{array}{l}\text { DNRA } \\
\text { rate }\end{array}$ & $\begin{array}{l}\text { Diversity } \\
\text { of DNRA } \\
\text { microbes }\end{array}$ \\
\hline$\overline{\text { DNRA rate }}$ & $0.43^{*}$ & -0.09 & -0.20 & -0.22 & 0.32 & -0.37 & $0.46^{*}$ & $0.43^{*}$ & $0.64^{\star *}$ & $0.52^{\star \star}$ & $0.49^{*}$ & I & $0.49^{*}$ \\
\hline $\begin{array}{l}\text { nrfA gene } \\
\text { abundance }\end{array}$ & $0.66^{\star *}$ & -0.40 & -0.16 & -0.38 & 0.14 & $-0.42^{*}$ & $0.82^{* *}$ & $0.65^{* *}$ & $0.63^{\star \star}$ & $0.83^{\star \star}$ & I & $0.49^{*}$ & $0.82^{* *}$ \\
\hline $\begin{array}{l}n r f A \text { gene } \\
\text { transcript }\end{array}$ & $0.75^{\star \star}$ & $-0.47^{*}$ & -0.17 & $-0.41^{*}$ & 0.18 & $-0.58^{\star *}$ & $0.77^{\star \star}$ & $0.78^{* *}$ & $0.58^{\star \star}$ & I & $0.83^{\star \star}$ & $0.52^{\star \star}$ & $0.86^{\star \star}$ \\
\hline
\end{tabular}

Note: "*” and "**” labeled on $r$ values denote $P<0.05$ and $P<0.01$, respectively. 


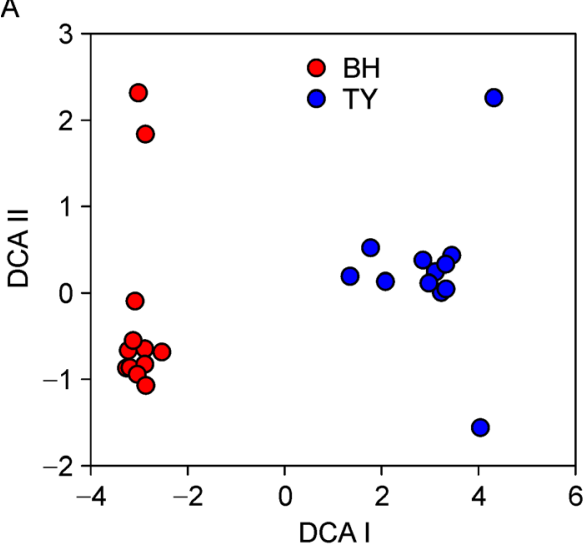

B

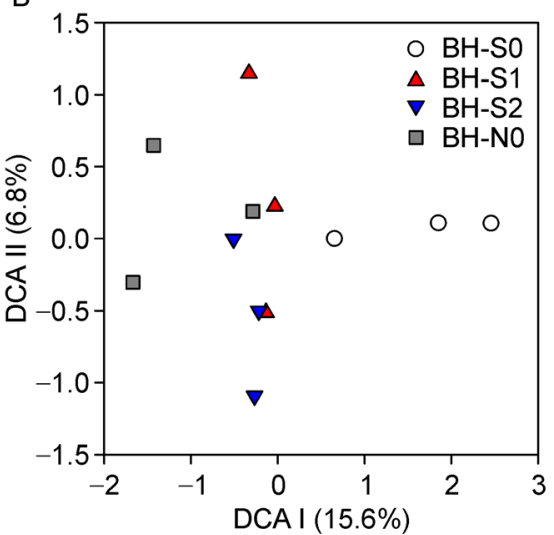

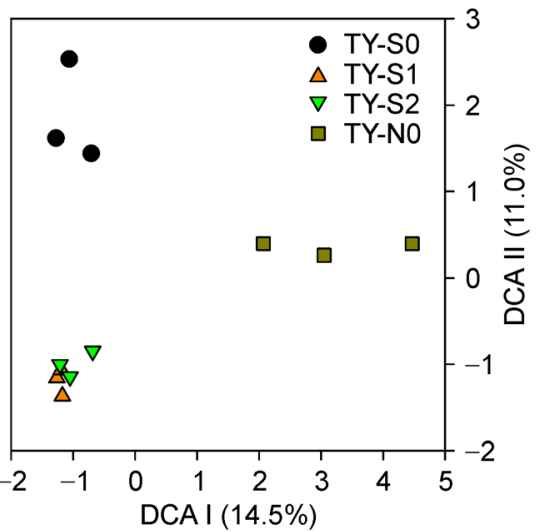

Fig. 4 Detrended correspondence analysis (DCA) for DNRA microbial community in two soil types (A) and within each soil type (B) based on nrfA gene transcripts from ${ }^{15} \mathrm{NO}_{3}{ }^{-}$incubation.

soil. Mantel test further indicated that soil $\mathrm{pH}$ and $\mathrm{C} / \mathrm{N}$ significantly influenced the community structure of active DNRA microbes (Table 3), indicating the significant effects from soil type, straw and nitrogen amendments.

Each representative sequence of the top 100 OTUs (representing more than $44.5 \%$ of $n r f A$ gene reads in each sample) were selected for further phylogenetic analysis (Fig. S2). Annotation of nrfA sequences retrieved from cDNA revealed that the active nrfA-gene containers were mainly affiliating within phyla Proteobacteria, Chloroflexi, Verrucomicrobia, Bacteroides, Actinobacteria, Planctomycetes and Hydrogenophilalia (Fig. 5). For both soil types, Deltaproteobacteria were the most dominant group, with a relative abundance between $30.9 \%$ Proteobacteria to $67.4 \%$.
Table 3 Mantel test for DNRA microbial community structure based on nrfA gene transcripts and soil physiochemical properties.

\begin{tabular}{lcc}
\hline $\begin{array}{l}\text { Environmental } \\
\text { parameters }\end{array}$ & $r$ & $P$ \\
\hline $\mathrm{pH}$ & $\mathbf{0 . 5 6 5}$ & 0.001 \\
$\mathrm{Eh}$ & 0.087 & 0.199 \\
$\mathrm{DOC}$ & -0.014 & 0.508 \\
$\mathrm{NH}_{4}{ }^{+}$ & 0.106 & 0.192 \\
$\mathrm{NO}_{3}{ }^{-}$ & -0.202 & 0.957 \\
Total C $^{-}$ & 0.021 & 0.417 \\
Total N & 0.134 & 0.058 \\
$\mathrm{C} / \mathrm{N}$ & $\mathbf{0 . 2 3 5}$ & 0.001 \\
$\mathrm{C} / \mathrm{NO}_{3}{ }^{-}$ & -0.155 & 0.836 \\
\hline
\end{tabular}

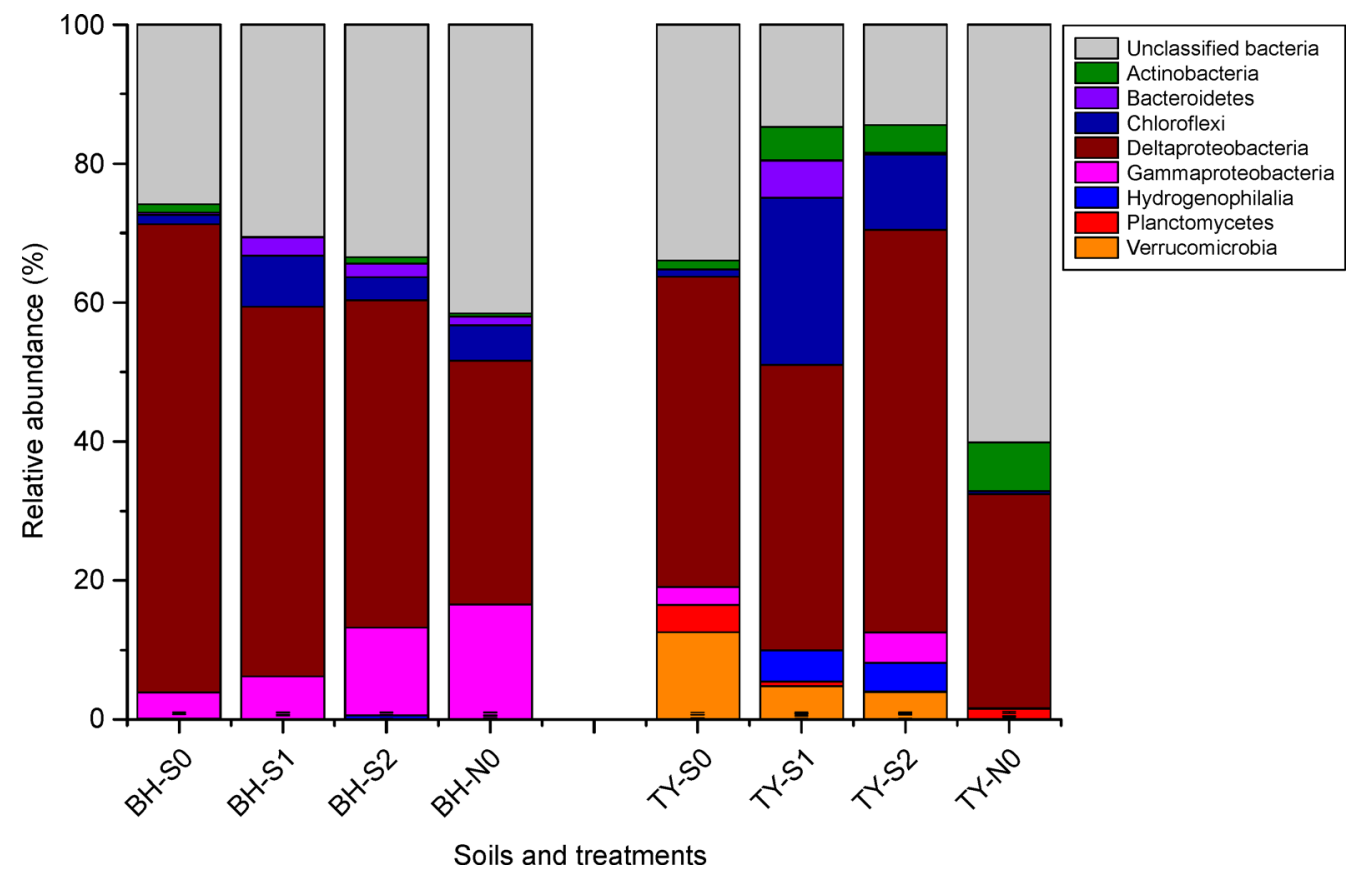

Fig. 5 Community composition of DNRA microbes based on top 100 OTUs of $n r f A$ gene transcripts retrieved from ${ }^{15} \mathrm{NO}_{3}{ }^{-}$incubation soils. 
In the $\mathrm{BH}$ soil, the relative abundance of Deltaproteobacteria gradually decreased from $67.40 \%$ to $35.14 \%$ following the order of S0, S1, S2 and N0, while the relative abundance of Gammaproteobacteria gradually increased from $3.78 \%$ to $16.45 \%$ correspondingly (Fig. 5). In the TY soil, the lowest relative abundance of Deltaproteobacteria was also recorded in N0 treatment, and the phylum Verrucomicrobia which was hardly detected in the $\mathrm{BH}$ soils, decreased from $12.56 \%$ to 0 following the order of S0, S1, S2 and N0 (Fig. 5). By comparing with S0 treatment (with a proportion of $1.28 \%$ ), the relative abundance of Actinobacteria was significantly higher in straw amendment treatments (S1, S2 and N0, 3.97\%$7.03 \%$ ) in the TY soil. Moreover, significantly higher proportions of Chloroflexi were observed in S1 $(24.05 \%)$ and S2 $(10.88 \%)$ than in S0 and N0 treatments in the TY soil (Fig. 5). All these suggested that straw incorporation and nitrogen fertilization had great influence on the active DNRA microbial community. In both soils, the proportion of unclassified nrfA gene sequences was highest in NO treatment $(41.6 \%$ and $60.1 \%$ in $\mathrm{BH}$ and $\mathrm{TY}$, respectively), suggesting that some taxonomy unknown bacteria may be responsible for active DNRA under high straw amendment but low $\mathrm{N}$ fertilizer input.

The retrieved NrfA amino acid sequences were further assigned to different clades referring to Welsh's classification based on known NrfA amino acid sequences (Fig. S2) (Welsh et al., 2014). Specifically, 79 out of the 100 OTUs primarily grouped into clade $\mathrm{J}$ and clade $\mathrm{K}$ which were mainly reported in agricultural soils, and 15 OTUs fell into clade A, C, D, H, L, $\mathrm{M}, \mathrm{N}$ and $\mathrm{O}$ based on previous classification (Welsh et al., 2014). The remaining 6 OTUs, forming an isolated branch in the phylogenetic tree, were not affiliated to any previously known clades or environmental sequences, thus were named as Unknown clade in this study (Fig. S2).

\section{Discussion}

DNRA process is beneficial to $\mathrm{N}$ retention and immobilization in agricultural soils since $\mathrm{N}$ is converted to resultant $\mathrm{NH}_{4}{ }^{+}$, rather than lost through denitrification and anammox. Our study based on a two-year pot experiment showed that DNRA was detectable with rates of 0.24 to $2.73 \mathrm{nmol} \mathrm{N} \mathrm{g}^{-1} \mathrm{~h}^{-1}$ in paddy soils with normal fertilization management. The value is comparable to previous studies showing the rates ranged from 2.37 to $8.31 \mathrm{nmol} \mathrm{N} \mathrm{g}{ }^{-1} \mathrm{~h}^{-1}$ in paddy soils (Yin et al., 2002, Lu et al., 2012, Pandey et al., 2016; Shan et al., 2016). Our work further quantified the abundance and transcriptional activity of nrfA gene in paddy soils, and revealed high nrfA gene abundance up to $\sim 10^{10}$ copy $g^{-1}$ dry soil and detectable nrfA gene transcription activity at $\sim 10^{6}$ copy $\mathrm{g}^{-1}$ dry soil in paddy soils under fertilization management. The results were consistent with previous studies reporting the high nrfA gene abundance (approximately $10^{8}-10^{11}$ copy $\mathrm{g}^{-1}$ dry sediment) in aquatic and wetland sediments (Song et al., 2014; Bu et al., 2017; Yin et al., 2017; Zhao et al., 2020), in contrast to the lower abundance $\left(10^{7}-10^{8}\right.$ copy $\mathrm{g}^{-1}$ dry soil) in upland agricultural soils (Pandey et al., 2018; Putz et al., 2018). We further found greater $n r f A$ gene abundance and transcriptional activity in alkaline $\mathrm{BH}$ soil than in acidic TY soil, corresponding to the relatively higher DNRA rates in the $\mathrm{BH}$ soil than in the TY soil. Consistently, higher DNRA rates in alkaline than in acidic and neutral paddy soils were also observed and attributed to the trigger effect from higher nitrification rates in high pH soils (Zhang et al., 2014). All these suggested DNRA process is active and may play an important role in maintaining $\mathrm{N}$ supply in paddy soils, particularly in the alkaline paddy soils.

We further found that straw amendment significantly enhanced DNRA rates, nrfA gene abundance and transcription activity, and that DNRA rates were significantly correlated to $\mathrm{C} / \mathrm{N}$ and $\mathrm{C} / \mathrm{NO}_{3}{ }^{-}$. This finding is supported by previous reports that the activity and biomass of DNRA bacteria dominated over denitrification bacteria under higher acetate/ $\mathrm{NO}_{3}{ }^{-}$ratios in laboratory incubation (van den Berg et al. 2016), and that DNRA microbes were also considered to be more effective in utilizing electron acceptors (i.e., $\mathrm{NO}_{3}{ }^{-}$) than denitrifiers (van den Berg et al., 2016; van den Berg et al., 2017). It was also found that the microbe like Shewanella loihica, is able to alternatively trigger both denitrification and DNRA processes in light of $\mathrm{C} / \mathrm{N}$ in chemostat to maximize energy conservation (Yoon et al., 2015). Similarly, significant enhancement of DNRA rates by cattle manure application was observed in paddy soils (Lu et al., 2012), and dry land agricultural soils with higher soil organic matter (SOM) was found to possess greater DNRA rates and higher nrfA gene abundance (Putz et al., 2018). We also found that the promotion effect of straw amendment on DNRA rates, nrfA gene abundance and transcription activity was much greater in the alkaline BH soil than the acidic TY soil. This could be explained by different soil property between two soil types. Some studies also claimed that DNRA are not necessarily enhanced by organic carbon addition due to the high native $C$ content or unfavorable redox conditions for DNRA microbes (Rütting et al., 2011; Liu et al., 2016). Rahman and colleagues (2019) also reported a greater improvement of DNRA activity by addition of natural organic carbon (NOC) substrates rather than acetate amendment in urban wetlands, and attributed this to the stimulation of NOC on fermentative DNRA by nitrate ammonifying bacteria. All these together with our observation suggested that organic $\mathrm{C}$ input and $\mathrm{C} / \mathrm{N}$ or $\mathrm{C} / \mathrm{NO}_{3}{ }^{-}$enhancement are generally beneficial to DNRA activity but dependent on the type of $\mathrm{C}$ sources and soil type. On the other hand, remarkable downward trends of $\mathrm{NH}_{4}{ }^{+} \mathrm{N}$ concentration with increased straw incorporation level across S0 to S2 were found in both soils. These could be attributed to microbial $\mathrm{N}$ assimilation under high organic condition as observed in previous studies (Huang et al., 2004; Huang et al., 2019).

In addition to organic $\mathrm{C}$ amendment, recent studies have also highlighted that nitrogen fertilization level can regulate DNRA via altering $\mathrm{C} / \mathrm{N}$ in paddy soils (Pandey et al., 2018, 2019). Similarly, higher DNRA rates in the low $N$ treatment soils while higher denitrification rates in the high $\mathrm{N}$ treatment soils were reported in the dry land agricultural soils with low 
organic matter, implying that higher $\mathrm{C} / \mathrm{N}$ caused by low $\mathrm{N}$ input could lead to higher DNRA rates (Putz et al., 2018). However, in our study, NO treatment without $\mathrm{N}$ fertilization but with straw amendment showed no significant difference to $\mathrm{S} 2$ treatment (with $\mathrm{N}$ fertilizer and straw amendment) in DNRA rates, $n r f A$ gene abundance and transcriptional activity in the $\mathrm{BH}$ soil. This could be explained by the stronger effect of straw incorporation over nitrogen depletion on DNRA microbe in this alkaline paddy soil. In contrast, a significant drop in nrfA gene abundance and transcriptional activity in NO treatment was observed in the acidic TY soil in comparison with S2. This could be caused by low pH in N0 (6.4) in comparison with other treatments (7.2-7.4), as DNRA process was supposed to be favored at alkaline and neutral condition than at acidic environment (Yoon et al., 2015). The N0 treatment was newly established and flooded before soil sampling and the effect of $\mathrm{pH}$ improvement by flooding was not strong as S0-S2 treatments in their second year in acidic red soil. The DNRA microbial community structure in NO treatment was clearly separated from S1 and S2 treatments in the TY soil while the pattern was not observed in the $\mathrm{BH}$ soil (Fig. 4). This either could be explained by soil $\mathrm{pH}$ difference between NO and other treatments, as numerous studies have suggested that $\mathrm{pH}$ is a major factor predicting soil microbial distribution pattern (Lauber et al., 2009; Griffiths et al., 2011). Further study is necessary to determine if low $\mathrm{pH}$ inhibits the transcriptional activity of $n r f A$ genes. In addition, we found that $n r f A$ gene abundance significantly decreased over time in 2016, indicating a declined effect from straw incorporation. Considering the facts that rice straw amendment could effectively improve DNRA while high $\mathrm{N}$ input had reverse effect on DNRA as observed in this study and above mentioned studies, together with our previous finding that straw amendment had potential risk in enhancing $\mathrm{N}_{2} \mathrm{O}$ emission in the same soils (Wang et al., 2018b), we recommended that simultaneous application of both nitrogen fertilizers and rice straws should be avoided in paddy rice fields.

Diversity and community structure of DNRA microbes are also essential indicators of DNRA process. Sequencing of $n r f A$ transcripts from mRNA is helpful to identify the activated DNRA microbes, which could better decipher the functionrelated community than that based at DNA level. To date, the information on the community composition of DNRA microbes are still limited, and the available studies so far were conducted by solely targeting on nrfA gene at DNA level (Song et al., 2014; Bu et al., 2017; Luvizotto et al., 2018; Pang and Ji, 2019). Our study showed that the active nrfA geneharboring microbes were mainly affiliating within Deltaproteobacteria phylum in both $\mathrm{BH}$ and TY soils, and the proportion of Gammaproteobacteria-affiliating microbes was greatly increased with straw amendment in the $\mathrm{BH}$ soil. Consistently, high proportions of Deltaproteobacteria in DNRA microbial communities were reported in the estuary and lake sediments (Bu et al., 2017; Pang and Ji, 2019). All these suggested that microbes affiliating with Deltaproteobacteria were probably the active and dominant microbial groups functioning in DNRA process. These previous studies also found a certain proportion of Gammaproteobacteria, Chloroflexi and Verrucomicrobia in river samples and lake sediments (Bu et al., 2017; Pang and Ji, 2019). Likewise, in this study, Gammaproteobacteria and Chloroflexi were also frequently detected in both soils and Verrucomicrobia occupied a certain proportion in the TY soil. In addition, we found that the relative abundance of Chloroflexi in both soils, Gammaproteobacteria in the $\mathrm{BH}$ soil and Actinobacteria in the TY soil were greatly increased with straw amendment, while Verrucomicrobia showed reverse trend and even disappeared in N0 treatment in the TY soil (Fig. 5). All these suggested that these groups might be sensitive to the change of $\mathrm{C} / \mathrm{N}$ induced by straw amendment. Among these groups, Gammaproteobacteria are supposed to be heterotrophic bacteria which can effectively utilize dissolved organic carbon as substrates (Nikrad et al., 2014), and Verrucomicrobia are supposed to have greater affinity to slow-decomposing organic carbon components rather than fast-decomposing organic carbon (Hale et al., 2019). Some studies also found that the diversity of Actinobacteria were positively correlated to organic carbon and C/N status (de Menezes et al., 2015; Chen et al., 2016; Liu et al., 2017). All these suggested that these groups are functionally important microbes mediating DNRA process but sensitive to environmental condition change including carbon, nitrogen and $\mathrm{pH}$ etc.

Phylogenetic analysis of the dominant representative OTUs sequences of $n r f A$ gene transcripts indicated that $79 \%$ of dominant OTUs retrieved in this study were affiliated within clades $\mathrm{J}$ and $\mathrm{K}$ based on Welsh's classification, and the clades was largely comprised of sequences from North American soil samples (Welsh et al., 2014), but were far from those retrieved from the estuary (Song et al., 2014). Clades $\mathrm{J}$ and $\mathrm{K}$ were also close to the environmental sequences from wastewater sludges and bioreactors in our phylogenetic tree (Fig. S2). These together with our results implied that different DNRA microbial groups have differentiated ecological and physiological niche, and clades $\mathrm{J}$ and $\mathrm{K}$ probably favor terrestrial environments and potentially play an important role in DNRA process in terrestrial ecosystems.

\section{Conclusions}

In the present study, stable isotope tracer combining molecular ecology techniques provided solid evidence that DNRA process could be significantly improved by the addition of straw in paddy soils, particularly in alkaline soil. Specifically, the DNRA rates, nrfA gene abundance and transcription activity were positively correlated to the promoted $\mathrm{C} / \mathrm{N}$ induced by the straw amendment, and significantly higher in alkaline soil than in acidic soil. Sequencing analysis based on nrfA gene transcripts showed that the active DNRA microbes were dominated by Deltaproteobacteria in both paddy soils, while straw amendment enriched some specific functional groups such as Gammaproteobacteria in the alkaline soils 
and Actinobacteria and Chloroflexi in the acidic soils. These results provided new insights into the diversity, potential taxa and activity of functional microbes involved in DNRA process in paddy soil ecosystem and provided critical information for the management of straw returning and nitrogen fertilization practices in agricultural soils.

\section{Acknowledgments}

This work was financially supported by the National Natural Science Foundation of China (41771288) and National Key Research and Development Program (2017YFE0109800). Limei Zhang was supported by the Youth Innovation Promotion Association (2012031), Chinese Academy of Sciences. We would like to thank Dr. Haijun Hou and Dr. Lili Han for assistance in soil sampling, and Dr. Juntao Wang, Miss Pengxia Xu, Feng Liu and Yun Wei for technical support and pot experiment management.

\section{Electronic supplementary material}

Supplementary material is available in the online version of this article at https://doi.org/10.1007/s42832-020-0050-6 and is accessible for authorized users.

\section{References}

An, S., Gardner, W.S., 2002. Dissimilatory nitrate reduction to ammonium (DNRA) as a nitrogen link, versus denitrification as a sink in a shallow estuary. Marine Ecology Progress Series 237, 41-50.

Bohlen, L., Dale, A.W., Sommer, S., Mosch, T., Hensen, C., Noffke, A., Scholz, F., Wallmann, K., 2011. Benthic nitrogen cycling traversing the Peruvian oxygen minimum zone. Geochimica et Cosmochimica Acta 75, 6094-6111.

Bu, C., Wang, Y., Ge, C., Ahmad, H.A., Gao, B., Ni, S.Q., 2017. Dissimilatory nitrate reduction to ammonium in the Yellow river estuary: rates, abundance, and community diversity. Scientific Reports 7, 6830.

Canfield, D.E., Glazer, A.N., Falkowski, P.G., 2010. The evolution and future of Earth's nitrogen cycle. Science 330, 192-196.

Chen, P., Zhang, L., Guo, X., Dai, X., Liu, L., Xi, L., Wang, J., Song, L., Wang, Y., Zhu, Y., Huang, L., Huang, Y., 2016. Diversity, biogeography, and biodegradation potential of Actinobacteria in the deep-sea sediments along the Southwest Indian Ridge. Frontiers in Microbiology 7, 1340.

Cheng, L., Li, X., Lin, X., Hou, L., Liu, M., Li, Y., Liu, S., Hu, X., 2016. Dissimilatory nitrate reduction processes in sediments of urban river networks: Spatiotemporal variations and environmental implications. Environmental Pollution 219, 545-554.

Chutivisut, P., Isobe, K., Powtongsook, S., Pungrasmi, W., Kurisu, F., 2018. Distinct Microbial Community performing dissimilatory nitrate reduction to ammonium (DNRA) in a high $\mathrm{C} / \mathrm{NO}_{3}{ }^{-}$reactor. Microbes and Environments 33, 264-271.

de Menezes, A.B., Prendergast-Miller, M.T., Poonpatana, P., Farrell,
M., Bissett, A., Macdonald, L.M., Toscas, P., Richardson, A.E., Thrall, P.H., 2015. C/N ratio drives soil actinobacterial cellobiohydrolase gene diversity. Applied and Environmental Microbiology 81, 3016-3028.

Dong, L.F., Smith, C.J., Papaspyrou, S., Stott, A., Osborn, A.M., Nedwell, D.B., 2009. Changes in benthic denitrification, nitrate ammonification, and anammox process rates and nitrate and nitrite reductase gene abundances along an estuarine nutrient gradient (the Colne estuary, United Kingdom). Applied and Environmental Microbiology 75, 3171-3179.

Friedl, J., De Rosa, D., Rowlings, D.W., Grace, P.R., Müller, C., Scheer, C., 2018. Dissimilatory nitrate reduction to ammonium (DNRA), not denitrification dominates nitrate reduction in subtropical pasture soils upon rewetting. Soil Biology \& Biochemistry 125, 340-349.

Gao, D., Li, X., Lin, X., Wu, D., Jin, B., Huang, Y., Liu, M., Chen, X., 2017. Soil dissimilatory nitrate reduction processes in the Spartina alterniflora invasion chronosequences of a coastal wetland of southeastern China: dynamics and environmental implications. Plant and Soil 421, 383-399.

Giblin, A.E., Weston, N.B., Banta, G.T., Tucker, J., Hopkinson, C.S., 2010. The effects of salinity on nitrogen losses from an Oligohaline estuarine sediment. Estuaries and Coasts 33, 1054-1068.

Griffiths, R.I., Thomson, B.C., James, P., Bell, T., Bailey, M., Whiteley, A.S., 2011. The bacterial biogeography of British soils. Environmental Microbiology 13, 1642-1654.

Guo, L., Lin, E., 2001. Carbon sink in cropland soils and the emission of greenhouse gases from paddy soils: a review of work in China. Chemosphere. Global Change Science 3, 413-418.

Hale, L., Feng, W., Yin, H., Guo, X., Zhou, X., Bracho, R., Pegoraro, E., Penton, C.R., Wu, L., Cole, J., Konstantinidis, K.T., Luo, Y., Tiedje, J.M., Schuur, E.A.G., Zhou, J., 2019. Tundra microbial community taxa and traits predict decomposition parameters of stable, old soil organic carbon. ISME Journal 13, 2901-2915.

Hardison, A.K., Algar, C.K., Giblin, A.E., Rich, J.J., 2015. Influence of organic carbon and nitrate loading on partitioning between dissimilatory nitrate reduction to ammonium (DNRA) and $\mathrm{N}_{2}$ production. Geochimica et Cosmochimica Acta 164, 146-160.

Huang, R., Wang, Y., Liu, J., Li, J., Xu, G., Luo, M., Xu, C., Ci, E., Gao, M., 2019. Variation in $\mathrm{N}_{2} \mathrm{O}$ emission and $\mathrm{N}_{2} \mathrm{O}$ related microbial functional genes in straw- and biochar-amended and nonamended soils. Applied Soil Ecology 137, 57-68.

Huang, Y., Zou, J., Zheng, X., Wang, Y., Xu, X., 2004. Nitrous oxide emissions as influenced by amendment of plant residues with different C:N ratios. Soil Biology \& Biochemistry 36, 973-981.

Jones, L.Z., Jasper, J.T., Sedlak, D.L., Sharp, J.O., 2017. Sulfideinduced dissimilatory nitrate reduction to ammonium supports anaerobic ammonium oxidation (Anammox) in an open-water unit process wetland. Applied and Environmental Microbiology 83, e00782-e17.

Kraft, B., Strous, M., Tegetmeyer, H.E., 2011. Microbial nitrate respiration: genes, enzymes and environmental distribution. Biotechnology Journal 155, 104-117.

Kumar, S., Nei, M., Dudley, J., Tamura, K., 2008. MEGA: A biologistcentric software for evolutionary analysis of DNA and protein sequences. Briefings in Bioinformatics 9, 299-306. 
Lauber, C.L., Hamady, M., Knight, R., Fierer, N., 2009. Pyrosequencing-based assessment of soil $\mathrm{pH}$ as a predictor of soil bacterial community structure at the continental scale. Applied and Environmental Microbiology 75, 5111-5120.

Li, X., Gao, D., Hou, L., Liu, M., 2019a. Soil substrates rather than gene abundance dominate DNRA capacity in the Spartina alterniflora ecotones of estuarine and intertidal wetlands. Plant and Soil 436, 123-140.

Li, X., Sardans, J., Hou, L., Gao, D., Liu, M., Peñuelas, J., 2019b. Dissimilatory nitrate/nitrite reduction processes in river sediments across climatic gradient: influences of biogeochemical controls and climatic temperature regime. Journal of Geophysical Research. Biogeosciences 124, 2305-2320.

Liu, D., Fang, Y., Tu, Y., Pan, Y., 2014. Chemical method for nitrogen isotopic analysis of ammonium at natural abundance. Analytical Chemistry 86, 3787-3792.

Liu, X., Cong, J., Lu, H., Xue, Y., Wang, X., Li, D., Zhang, Y., 2017. Community structure and elevational distribution pattern of soil Actinobacteria in alpine grasslands. Acta Ecologica Sinica 37, 213-218.

Liu, X., Han, J.G., Ma, Z.W., Wang, Q., Li, L.H., 2016. Effect of carbon source on dissimilatory nitrate reduction to ammonium in costal wetland sediments. Journal of Soil Science and Plant Nutrition 16, 337-349.

Liu, Y., Ge, T., Zhu, Z., Liu, S., Luo, Y., Li, Y., Wang, P., Gavrichkova, O., Xu, X., Wang, J., Wu, J., Guggenberger, G., Kuzyakov, Y., 2019. Carbon input and allocation by rice into paddy soils: A review. Soil Biology \& Biochemistry 133, 97-107.

Lu, W., Zhang, H., Min, J., Shi, W., 2015. Dissimilatory nitrate reduction to ammonium in a soil under greenhouse vegetable cultivation as affected by organic amendments. Journal of Soils and Sediments 15, 1169-1177.

Lu, W.W., Riya, S., Zhou, S., Hosomi, M., Zhang, H.L., Shi, W.M., 2012. In situ dissimilatory nitrate reduction to ammonium in a paddy soil fertilized with liquid cattle waste. Pedosphere 22, 314 321.

Lu, W.W., Zhang, H.L., Shi, W.M., 2013. Dissimilatory nitrate reduction to ammonium in an anaerobic agricultural soil as affected by glucose and free sulfide. European Journal of Soil Biology 58, 98 104.

Luvizotto, D.M., Araujo, J.E., Silva, M.C.P., Dias, A.C.F., Kraft, B., Tegetmeye, H., Strous, M., Andreote, F.D., 2018. The rates and players of denitrification, dissimilatory nitrate reduction to ammonia (DNRA) and anaerobic ammonia oxidation (anammox) in mangrove soils. Anais da Academia Brasileira de Ciências.

Minick, K.J., Pandey, C.B., Fox, T.R., Subedi, S., 2016. Dissimilatory nitrate reduction to ammonium and $\mathrm{N}_{2} \mathrm{O}$ flux: effect of soil redox potential and $\mathrm{N}$ fertilization in loblolly pine forests. Biology and Fertility of Soils 52, 601-614.

Mohan, S.B., Schmid, M., Jetten, M., Cole, J., 2004. Detection and widespread distribution of the $n r f A$ gene encoding nitrite reduction to ammonia, a short circuit in the biological nitrogen cycle that competes with denitrification. FEMS Microbiology Ecology 49, 433-443.

Nikrad, M.P., Cottrell, M.T., Kirchman, D.L., 2014. Uptake of dissolved organic carbon by gammaproteobacterial subgroups in coastal waters of the West Antarctic Peninsula. Applied and Environmental Microbiology 80, 3362-3368.

Palacin-Lizarbe, C., Camarero, L., Hallin, S., Jones, C.M., Caliz, J., Casamayor, E.O., Catalan, J., 2019. The DNRA-denitrification dichotomy differentiates nitrogen transformation pathways in mountain lake benthic habitats. Frontiers in Microbiology 10, 1229.

Pandey, A., Suter, H., He, J.Z., Chen, D., 2016. Dissimilatory nitrate reduction to ammonium, denitrification and anaerobic ammonium oxidation in paddy soil. Proceedings of the 2016 International Nitrogen Initiative Conference.

Pandey, A., Suter, H., He, J.Z., Hu, H.W., Chen, D., 2018. Nitrogen addition decreases dissimilatory nitrate reduction to ammonium in rice paddies. Applied and Environmental Microbiology 84, e00870-e18.

Pandey, A., Suter, H., He, J.Z., Hu, H.W., Chen, D., 2019. Dissimilatory nitrate reduction to ammonium dominates nitrate reduction in long-term low nitrogen fertilized rice paddies. Soil Biology \& Biochemistry 131, 149-156.

Pang, Y., Ji, G., 2019. Biotic factors drive distinct DNRA potential rates and contributions in typical Chinese shallow lake sediments. Environmental Pollution 254, 112903.

Putz, M., Schleusner, P., Rütting, T., Hallin, S., 2018. Relative abundance of denitrifying and DNRA bacteria and their activity determine nitrogen retention or loss in agricultural soil. Soil Biology \& Biochemistry 123, 97-104.

Rahman, M.M., Roberts, K.L., Grace, M.R., Kessler, A.J., Cook, P.L. M., 2019. Role of organic carbon, nitrate and ferrous iron on the partitioning between denitrification and DNRA in constructed stormwater urban wetlands. Science of the Total Environment 666, 608-617.

Reyes, C., Schneider, D., Lipka, M., Thurmer, A., Bottcher, M.E., Friedrich, M.W., 2017. Nitrogen metabolism genes from temperate marine sediments. Marine Biotechnology (New York, N.Y.) 19, 175-190.

Robertson, E.K., Roberts, K.L., Burdorf, L.D.W., Cook, P., Thamdrup, B., 2016. Dissimilatory nitrate reduction to ammonium coupled to $\mathrm{Fe}$ (II) oxidation in sediments of a periodically hypoxic estuary. Limnology and Oceanography 61, 365-381.

Rütting, T., Boeckx, P., Müller, C., Klemedtsson, L., 2011. Assessment of the importance of dissimilatory nitrate reduction to ammonium for the terrestrial nitrogen cycle. Biogeosciences 8, 1779-1791.

Salk, K.R., Erler, D.V., Eyre, B.D., Carlson-Perret, N., Ostrom, N.E., 2017. Unexpectedly high degree of anammox and DNRA in seagrass sediments: description and application of a revised isotope pairing technique. Geochimica et Cosmochimica Acta 211, 64-78.

Shan, J., Zhao, X., Sheng, R., Xia, Y., Ti, C., Quan, X., Wang, S., Wei, W., Yan, X., 2016. Dissimilatory nitrate reduction processes in typical Chinese paddy soils: rates, relative contributions, and influencing factors. Environmental Science \& Technology 50, 9972-9980.

Song, B., Lisa, J.A., Tobias, C.R., 2014. Linking DNRA community structure and activity in a shallow lagoonal estuarine system. Frontiers in Microbiology 5, 460.

Stein, L.Y., Klotz, M.G., 2016. The nitrogen cycle. Current Biology 26, R94-R98. 
Strohm, T.O., Griffin, B., Zumft, W.G., Schink, B., 2007. Growth yields in bacterial denitrification and nitrate ammonification. Applied and Environmental Microbiology 73, 1420-1424.

van den Berg, E.M., Boleij, M., Kuenen, J.G., Kleerebezem, R., van Loosdrecht, M.C., 2016. DNRA and denitrification coexist over a broad range of acetate/ $\mathrm{N}-\mathrm{NO}_{3}{ }^{-}$ratios, in a chemostat enrichment culture. Frontiers in Microbiology 7, 1842.

van den Berg, E.M., Elisario, M.P., Kuenen, J.G., Kleerebezem, R., van Loosdrecht, M.C.M., 2017. Fermentative bacteria influence the competition between denitrifiers and DNRA bacteria. Frontiers in Microbiology 8, 1684.

Wang, N., Yu, J.G., Zhao, Y.H., Chang, Z.Z., Shi, X.X., Ma, L.Q., Li, H. B., 2018a. Straw enhanced $\mathrm{CO}_{2}$ and $\mathrm{CH}_{4}$ but decreased $\mathrm{N}_{2} \mathrm{O}$ emissions from flooded paddy soils: Changes in microbial community compositions. Atmospheric Environment 174, 171179.

Wang, Y.Q., Bai, R., Di, H.J., Mo, L.Y., Han, B., Zhang, L.M., He, J.Z., 2018b. Differentiated mechanisms of biochar mitigating strawinduced greenhouse gas emissions in two contrasting paddy soils. Frontiers in Microbiology 9, 2566.

Welsh, A., Chee-Sanford, J.C., Connor, L.M., Löffler, F.E., Sanford, R., 2014. Refined NrfA phylogeny improves PCR-Based nrfA gene detection. Applied and Environmental Microbiology 80, 2110 2119.

Wu, X.H., Wang, W., Xie, X.L., Yin, C.M., Hou, H.J., 2018. Effects of rice straw mulching on $\mathrm{N}_{2} \mathrm{O}$ emissions and maize productivity in a rain-fed upland. Environmental Science and Pollution Research International 25, 6407-6413.

Yan, X., Zhou, H., Zhu, Q.H., Wang, X.F., Zhang, Y.Z., Yu, X.C., Peng, $X ., 2013$. Carbon sequestration efficiency in paddy soil and upland soil under long-term fertilization in southern China. Soil \& Tillage Research 130, 42-51.

Yao, S.Q., Graoffman, P.M., Alewell, C., Ballantine, K., 2018. Soil amendments promote denitrification in restored wetlands. Restoration Ecology 26, 294-302.

Yin, G., Hou, L., Liu, M., Li, X., Zheng, Y., Gao, J., Jiang, X., Wang, R., Yu, C., Lin, X., 2017. DNRA in intertidal sediments of the Yangtze estuary. Journal of Geophysical Research. Biogeosciences 122, 1988-1998.

Yoon, S., Cruz-Garcia, C., Sanford, R., Ritalahti, K.M., Loffler, F.E., 2015. Denitrification versus respiratory ammonification: environmental controls of two competing dissimilatory $\mathrm{NO}_{3}{ }^{-} / \mathrm{NO}_{2}^{-}$reduction pathways in Shewanella loihica strain PV-4. ISME Journal 9, 1093-1104.

Zhang, J., Lan, T., Müller, C., Cai, Z., 2014. Dissimilatory nitrate reduction to ammonium (DNRA) plays an important role in soil nitrogen conservation in neutral and alkaline but not acidic rice soil. Journal of Soils and Sediments 15, 523-531.

Zhang, S., Fang, Y., Xi, D., 2015. Adaptation of micro-diffusion method for the analysis of ${ }^{15} \mathrm{~N}$ natural abundance of ammonium in samples with small volume. Rapid Communications in Mass Spectrometry 29, 1297-1306.

Zhao, Y., Bu, C., Yang, H., Qiao, Z., Ding, S., Ni, S., 2020. Survey of dissimilatory nitrate reduction to ammonium microbial community at national wetland of Shanghai, China. Chemosphere 250, 126195-126195.

Zhou, M., Butterbach-Bahl, K., Vereecken, H., Bruggemann, N., 2017. A meta-analysis of soil salinization effects on nitrogen pools, cycles and fluxes in coastal ecosystems. Global Change Biology 23, 1338-1352 